\title{
Composition and Distribution of Organic Carbon in River Sediments: a Case Study of Two Northern Chinese Rivers
}

\author{
Qing-Qing Cao', Ren-Qing Wang ${ }^{1,2}$, Jian Liu ${ }^{1 *}$ \\ 'Institute of Environmental Research, Shandong University, Jinan 250100, China \\ ${ }^{2}$ School of Life Science, Shandong University, Jinan 250100, China
}

Received: 14 December 2014

Accepted: 28 January 2015

\begin{abstract}
In order to explore the composition characteristics and distribution pattern of organic carbon (OC) in river sediments, river sediments and riverbank soils were sampled from upstream to downstream of the Majia and Tuhai rivers in northern China, and then determined for heavy fraction organic carbon (HFOC) and light fraction organic carbon (LFOC). Results showed that the HFOC had a significant correlation with LFOC in Majia riverbank sediments or soils, indicating that HFOC and LFOC might have homology and that the Majia River is relatively stable. The distribution pattern of OC is changing irregularly along with rivers. Mean HFOCs in sediments were slightly higher than that in riverbank soils in both studied rivers. Contributions of some other sources of OC that accumulated in sediments might result in better capacity of sediments to OC than soils of riverbank. Our study demonstrated that sediments could accumulate HFOC and LFOC derived from many sources, and had a better capability for the storage of OC, irrespective of HFOC and LFOC.
\end{abstract}

Keywords: HFOC, LFOC, Majia River, river sediment, Tuhai River

\section{Introduction}

Many studies have suggested that organic carbon (OC) storage in soils could alleviate the greenhouse effect [1, 2], and the research of carbon sequestration has become the hot topic of global change ecology [3]. The carbon in global soils was $2500 \mathrm{Gt}$, which was 3.3 times the size of the atmospheric pool and 2-3 times the carbon in global vegetation [2], including about $1,550 \mathrm{Gt}$ of soil organic carbon and $950 \mathrm{Gt}$ of soil inorganic carbon $[4,5]$. Storage of OC in soils of China was up to 1.5-3 times the amount of carbon stored in vegetation [6], and $\mathrm{OC}$ in river wetland should not be neglected in estimation of carbon storage considering that the wetland is an important carbon sink $[7,8]$.

*e-mail: ecology@sdu.edu.cn
The stability of different components in $\mathrm{OC}$ is not the same. Vegetation, microbes, and zoobenthos are the main ways for carbon to assimilate into soils [9-11]. In the processes of their decomposition, they are mainly decomposed into light fraction organic carbon (LFOC, specific gravity $\left.<1.7 \mathrm{~g} / \mathrm{cm}^{3}\right)[12,13]$, which is the active carbon pool and easy to be affected by environment and climate [14, $15]$. Then, LFOC is decomposed into heavy fraction organic carbon (HFOC, specific gravity $>1.7 \mathrm{~g} / \mathrm{cm}^{3}$ ) partially [16], which is relatively stable and complicated [17].

The studies of OC in rivers or terrestrial soils of China were mainly concentrated in southern China and most research did not distinguish between LFOC and HFOC [1820]. Carbon sequestration of river sediments can be explored in depth by analyzing HFOC and LFOC as they are the stable and active components of OC [21]. Therefore, the study of HFOC and LFOC in river sediments in north- 
ern China is meaningful for understanding the capability of rivers for carbon storage.

In order to understand the composition characteristics and distribution pattern of organic carbon in river sediments. We sampled sediments and soils on the banks of the Majia and Tuhai rivers from upstream to downstream. This study tries to answer the following scientific questions:

1. Is the distribution of HFOC and LFOC in river sediments consistent?

2. Is the distribution pattern of organic carbon in river sediments influenced by soils of riverbank or other factors?

\section{Materials and Methods}

\section{Study Area}

The Tuhai and Majia rivers belong to the Haihe River Basin, which empties into the Bohai Gulf. They mainly flow through Shandong Province, China, which has a typical warm temperate monsoon climate. Annual average temperature is $11 \sim 14^{\circ} \mathrm{C}$. The mean annual frost-free period is 220 days, and increases from northeast to the southwest coast of Shandong Province progressively [22].

\section{Field Sample Collection}

Sixty samples were selected from the sediments and soils on the banks of the Tuhai River $\left(36^{\circ} 07^{\prime} 26.3 \mathrm{~N}\right.$, $\left.115^{\circ} 28^{\prime} 35.0 \mathrm{E}-37^{\circ} 30^{\prime} 08.0 \mathrm{~N}, 117^{\circ} 51^{\prime} 08.0 \mathrm{E}\right)$ and Majia River $\left(36^{\circ} 18^{\prime} 42.8 \mathrm{~N}, 115^{\circ} 33^{\prime} 41.1 \mathrm{E}-37^{\circ} 45^{\prime} 46.4 \mathrm{~N}, 117^{\circ} 23^{\prime} 53.2 \mathrm{E}\right)$ in May 2014. Thirty samples were taken from each river, including 15 sediment samples and 15 soil samples. Nine, 3 , and 3 of the 15 samples were obtained from upstream, midstream, and downstream in sediments or riverbank in each river, respectively. To study the small-scale distribution pattern of OC in continuous segments of both rivers' sediments, we sampled three groups in the upstream, each of which included three successive sampling points, and interblock space was $2 \mathrm{~km}$, within every two sampling points of each group was 200 meters. Surface sediments (0-
$15 \mathrm{~cm}$ ) and soils were sampled into sealed bags by sediment sampler. Two cutting rings of soil samples were gotten at each sampling point (one was used to measure the moisture content, the other used to measure organic carbon). Sampling distribution was shown in Fig. 1.

\section{Statistical Analysis}

All data were analyzed using SPSS (version 21.0). OneWay ANOVA was used to determine the significant differences in both rivers from upstream to downstream, and bivariate correlations were analyzed in the relationship of HFOC and LFOC, sediments and soils on banks, certain functional constants, and OC. An outlier from soils on upstream Majia banks was rejected in the process of statistical analysis by SPSS. OriginPro (version 8.0) and Adobe illustrator (version 16.0.0) were used to draw the figures.

\section{Laboratory Analysis}

The modified gravity method was used to separate HFOC and LFOC [16]. The drying method was used to measure moisture content and bulk density [23]. HFOC, LFOC, and total nitrogen were determined by elemental analyzer (Vario EL III, Elementar Analysensysteme, Germany). The $\mathrm{pH}$ of soil and sediment samples was measured with a 1:2.5 soil-water ratio by $\mathrm{pH}$ meter.

\section{Results}

\section{The Composition and Distribution Characteristics of Organic Carbon in Sediments}

HFOC had a significant correlation with LFOC in Majia sediments $(\mathrm{r}=0.650, \mathrm{p}<0.05)$, as did that in Majia shore soil $(r=0.787, p<0.01$; Table 3$)$. However, the same correlation in Tuhai sediments or riverbank soils was not significant (Table 2). Distribution patterns of HFOC and LFOC in upstream continuous segments of the two rivers were changed irregularly (Figs. 2 and 4).

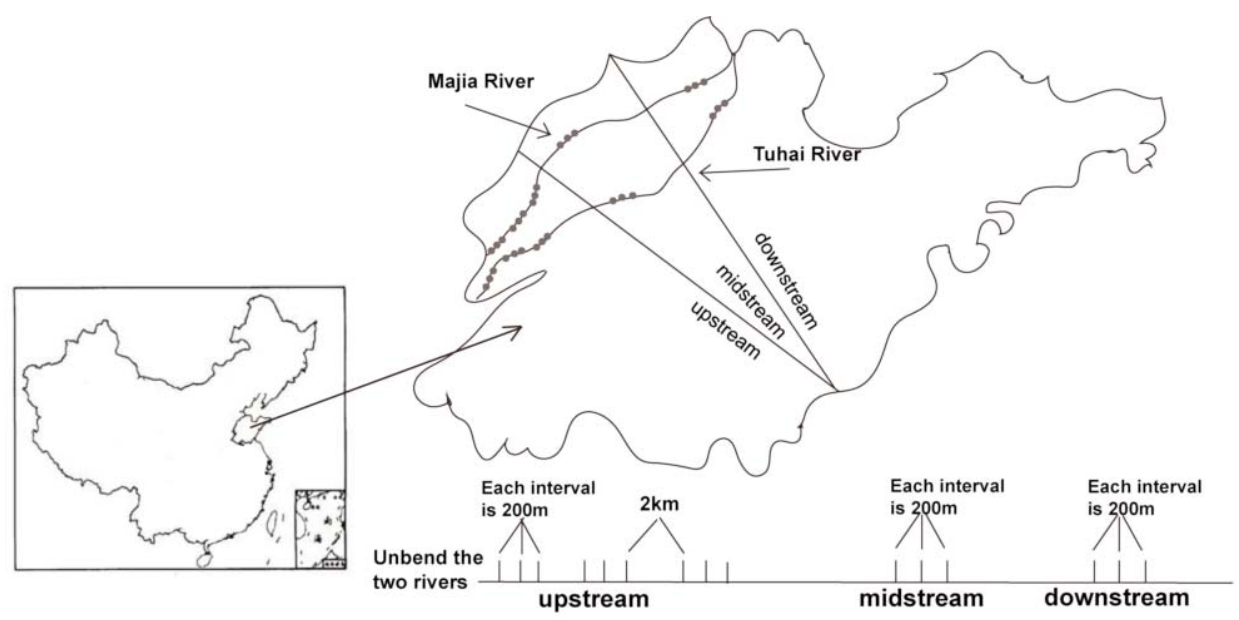

Fig. 1. The sampling points in the sediment of Majia and Tuhai River. 
Table 1. Mean contents of HFOC and LFOC, and mean C/N values in sediment and riverbank soil of the Tuhai and Majia (means \pm standard deviation; one extremum in the Majia was rejected by SPSS).

\begin{tabular}{|l|c|c|c|c|}
\hline \multicolumn{1}{|c|}{ Sample sites } & $\mathrm{n}$ & LFOC (\%) & HFOC (\%) & C/N \\
\hline Tuhai sediment & 15 & $0.064 \pm 0.081$ & $1.568 \pm 0.480$ & $1.412 \pm 0.281$ \\
\hline Tuhai shore soil & 15 & $0.065 \pm 0.060$ & $1.619 \pm 0.470$ & $25.169 \pm 10.216$ \\
\hline Majia sediment & 14 & $0.045 \pm 0.054$ & $1.332 \pm 0.419$ & $13.207 \pm 4.048$ \\
\hline Majia shore soil & 14 & $0.033 \pm 0.032$ & \\
\hline
\end{tabular}

By comparing the river sediments and soils on banks, we could see that the correlation of LFOC in the Tuhai was significant ( $r=0.723, \mathrm{p}<0.01$; Fig. 2 ) and mean LFOC in sediments and soils of riverbank was almost equal. However, the correlation of HFOC in the Tuhai was not significant $(\mathrm{r}=0.345, \mathrm{p}<0.05$; Table 2$)$, especially in midstream. HFOC and LFOC all had significant correlation between sediments and soils of the Majia shore (Table 3 and Fig. 4).

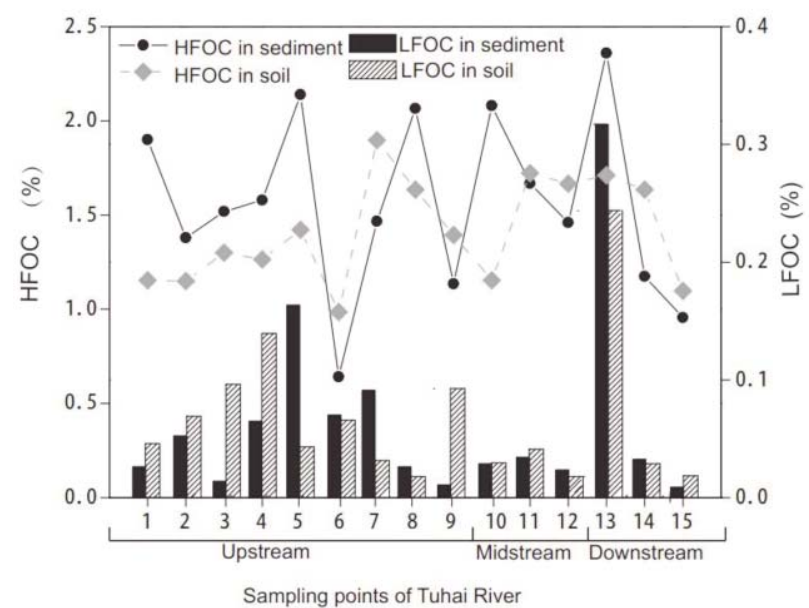

Fig. 2. The distribution of OC in the sediment and soil of Tuhai River shore.

\section{Comparison and Distribution Pattern of Organic Carbon in These Two Rivers}

LFOC was far less than that of HFOC at each sampling point of these two rivers (Table 1). And from the view of mean HFOC, Majia sediments $>$ Tuhai sediments $>$ soils of Tuhai shore $>$ soils of Majia shore. As for LFOC: Tuhai sediments $\approx$ soils of Tuhai shore $>$ Majia sediments $>$ soils of Majia shore. Mean HFOC in sediments was slightly higher than that in soils of riverbank, while the distribution of LFOC was not the same in these two rivers.

HFOC and LFOC in sediments were evenly distributed from upstream to downstream in the Tuhai, thus HFOC and LFOC were much higher in downstream Majia than that in upstream and midstream (Fig. 3).

\section{Effects of Environmental Factors on the Composition and Distribution of Organic Carbon}

Our study showed that $\mathrm{OC}$ was significantly correlated with total nitrogen (TN) in Majia sediments, particularly HFOC $(\mathrm{r}=0.958, \mathrm{p}<0.01)$, as was that in Majia shore soils (Figs. 5 and 6). HFOC was also significantly correlated

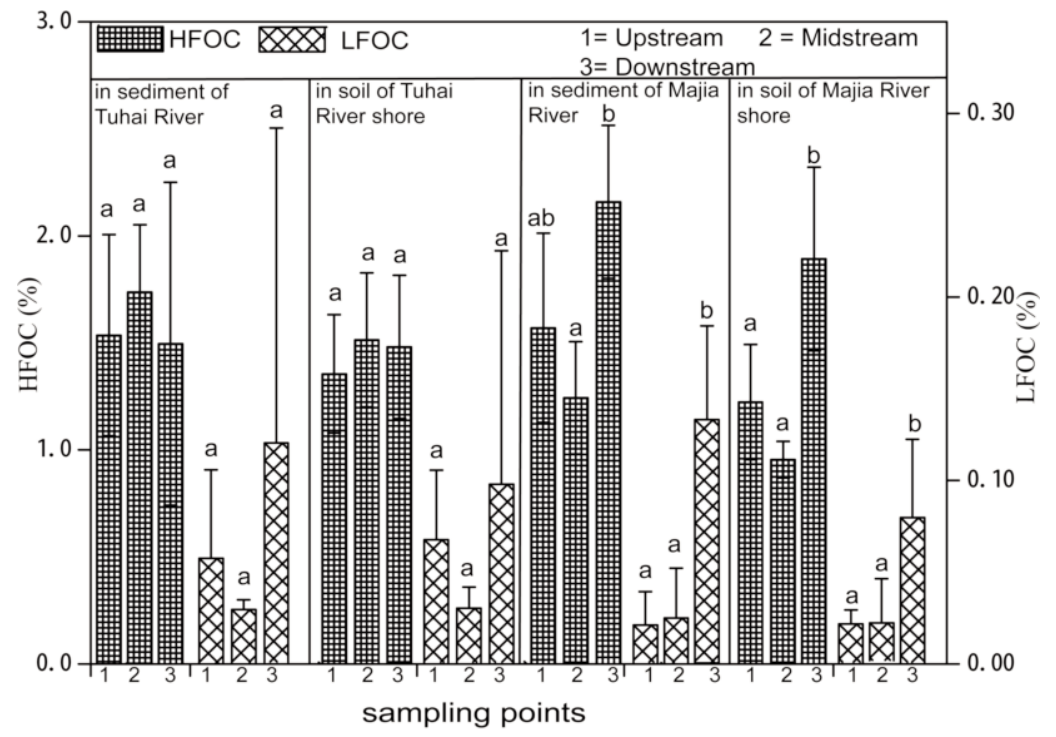

Fig. 3. The mean organic carbon in sediments and soils of the Tuhai and Majia River (Duncan test). The bars sharing the same letter have no difference at $\mathrm{p}<0.05$. 
Table 2. Pearson correlation analysis of HFOC and LFOC in sediment and soil on the banks of the Tuhai.

\begin{tabular}{|l|c|c|c|}
\hline \multicolumn{1}{|c|}{$\mathrm{r}$} & HFOC in Tuhai sediment & LFOC in Tuhai sediment & HFOC in Tuhai shore soil \\
\hline LFOC in Tuhai sediment & 0.507 & & \\
\hline HFOC in Tuhai shore soil & 0.345 & 0.309 & 0.048 \\
\hline LFOC in Tuhai shore soil & 0.285 & $0.723^{*}$ & \\
\hline
\end{tabular}

$\mathrm{n}=15, * \mathrm{p}<0.01$

with $\mathrm{TN}$ in Tuhai sediments $(\mathrm{r}=0.675, \mathrm{p}<0.05)$, while LFOC was not (Fig. 6). Mean carbon nitrogen ratio $(\mathrm{C} / \mathrm{N})$ of most sampling points in sediments of these two rivers was higher than that in riverbank soils (Table 1).

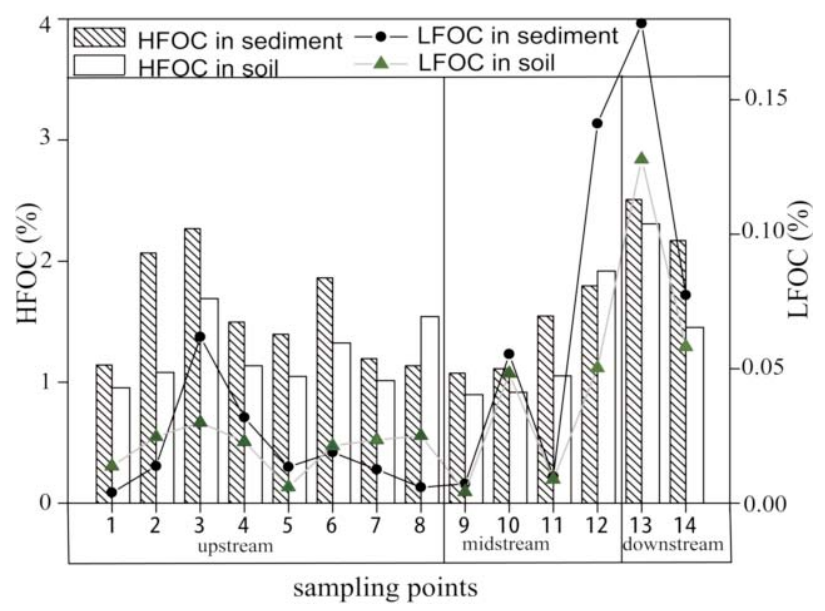

Fig. 4. The distribution of organic carbon in sediments and riverbank soils of Majia River.
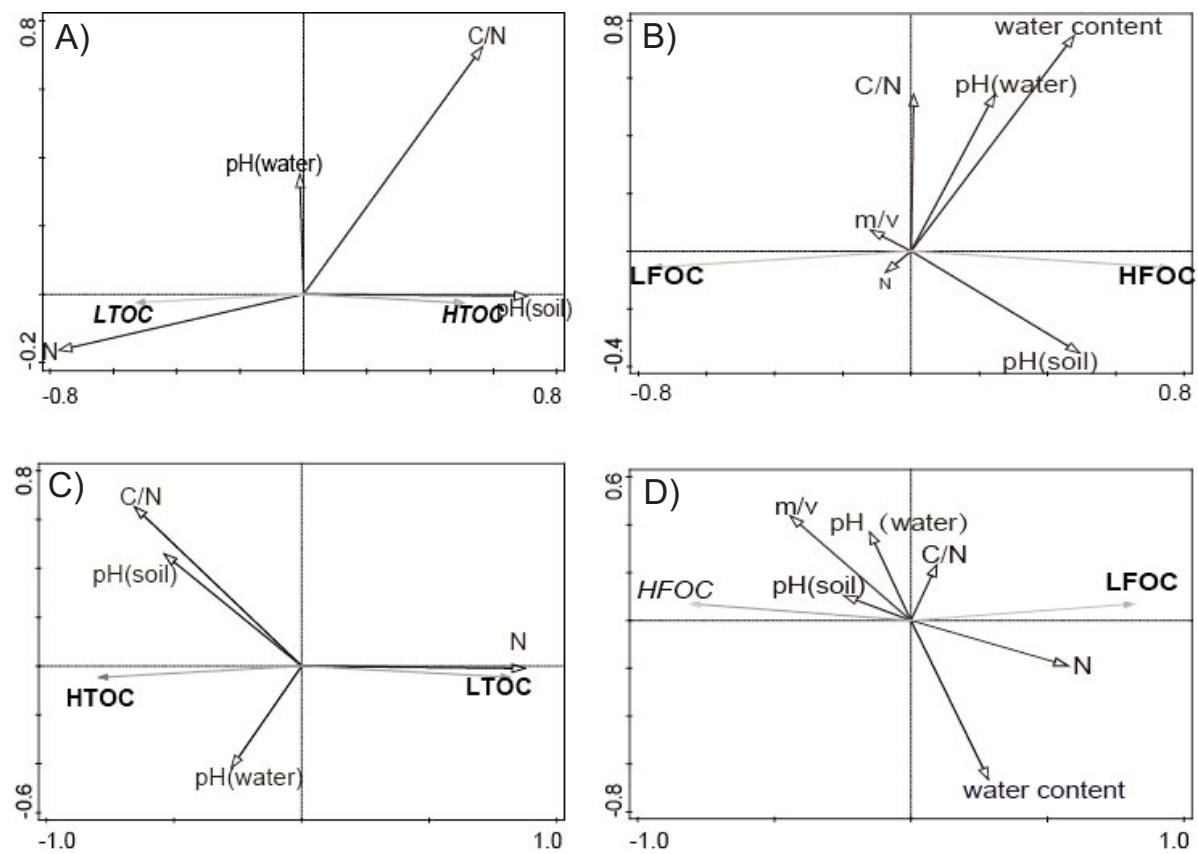

Fig. 5. Relationships between some environmental constants and organic carbon (HFOC, LFOC). A) Analysis of the relationship among the factors and organic carbon in Tuhai River Sediment; B) Analysis of the relationship among the factors and organic carbon in the soil on banks of Tuhai River; C) Analysis of the relationship among the factors and organic carbon in Majia River Sediment; D) Analysis of the relationship among the factors and organic carbon in the soil on banks of Majia River. 
Table 3. Pearson correlation analysis of HFOC and LFOC in Majia sediment and soil.

\begin{tabular}{|l|c|c|c|}
\hline \multicolumn{1}{|c|}{$\mathrm{r}$} & HFOC in Majia sediment & LFOC in Majia sediment & HFOC in Majia shore soil \\
\hline LFOC in Majia sediment & $0.650^{*}$ & & \\
\hline HFOC in Majia shore soil & $0.719^{* *}$ & $0.854^{* *}$ & $0.787^{* *}$ \\
\hline LFOC in Majia shore soil & $0.631^{*}$ & 0.89 \\
\hline
\end{tabular}

$\mathrm{n}=14,{ }^{*} \mathrm{p}<0.05, * * \mathrm{p}<0.01$

which might reveal that the interference in this river was mostly from human activity such as dredging of the midstream, tillage of the upstream, etc. The significant correlation of OC (HFOC and LFOC) in Majia sediments and soils further proved that $\mathrm{OC}$ between sediments and soils had homology, and the contribution of soils to sediments of HFOC and LFOC was very large, which might be related to the formation of surface sediments [27]. There were other parts of OC coming from the deposition of fine sediments $[28,29]$ and bacteria groups $[30,31]$ in river waters, microbial fixed effects in sediments to organic matter [32], and residues of zooplankton [33], etc.

Total nitrogen (TN) was one of the important indicators of nutrition levels and microbial abundance, which had much to do with TOC in sediments and soils [34]. The significant correlation of LFOC and TN in the Majia might be largely connected with primary producers and microbes (Fig. 5) [35]. The more significant correlation of HFOC with TN than LFOC in these two rivers might be that HFOC and TN were proportional to each other in many components of sediments and soils (Fig. 5) [34]. Carbon nitrogen ratio $(\mathrm{C} / \mathrm{N})$ might be an indicator of main origins and sources of OC [25]. Mean $\mathrm{C} / \mathrm{N}$ values in most Majia sampling points were less than that in the Tuhai overall, indicating that the sources of the Tuhai were relatively complicated. Besides, mean $\mathrm{C} / \mathrm{N}$ values in riverbank soils were slightly lower than that in the sediments of both rivers (Table 1), which proved that OC in sediments of both rivers had multiple sources.

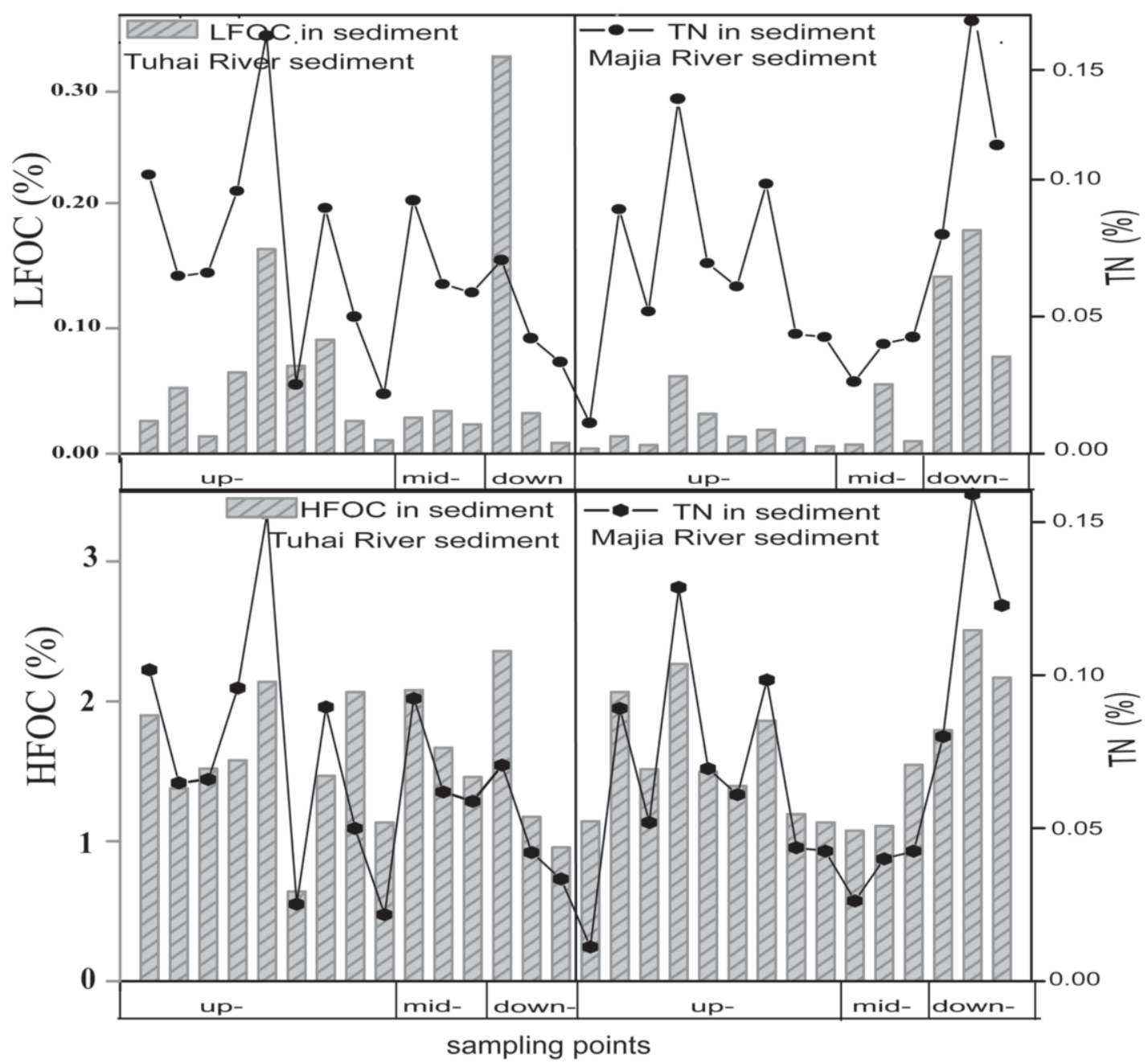

Fig. 6. The relationship between HFOC and TN, the relationship between LFOC and TN. 
Soil bulk density, moisture content and other physical constants were also indirectly associated with OC, whether through microbial activities or growth degree of primary productivity $[30,36]$. A previous study suggested that $\mathrm{OC}$ increased with moisture content and decreased with bulk density in soils [37]. However, it was not significant in our study as many other factors, including human interference, might influence river sediments.

With the perennial impact of rain on soils and the flow of river waters, OC in soils of riverbank and upstream gradually deposit in surface sediments, leading to the loss of a part of OC in riverbank soils [38]. Therefore, the mean HFOC in sediments was slightly higher than that in soils of riverbank and the high HFOC of river sediments indicated that sediments might have more capability to store HFOC than soils on corresponding banks. High LFOC upstream of the Tuhai might be caused by the residues of crops [39], which also might be proved by $\mathrm{C} / \mathrm{N}$ values and TN [40]. There were many microbes and plant residues accumulated in surface sediments, and organic components with high molecular weight derived from river waters gathered into sediments, causing the LFOC in Majia sediments to rise, though a very small fraction of carbon would decompose and be released into the atmosphere [41]. Results in our study suggest that sediments of natural rivers might have better capacity to store HFOC and LFOC than riverbank soils. By comparing the HFOC and LFOC between sediments and soils, and analyzing the results overall, we could find that the distribution trend of Majia HFOC and LFOC were in line with the normal characteristics of natural rivers, and the analysis above suggested that sediments could accumulate HFOC and LFOC that derived from many sources, and had better capability for OC storage.

\section{Conclusions}

Our results suggest that the Majia was relatively stable while the Tuhai was complicated and influenced by artificial factors. HFOC and LFOC in river sediments had multiple sources and they had homology in Majia sediments but not in the Tuhai. The distribution patterns of OC change irregularly along with rivers. All results demonstrated that river sediments have a better capability for storing OC, irrespective of HFOC and LFOC.

\section{Acknowledgements}

We would like to thank Qin Xu for her help with fieldwork, and Xinjuan Cui, Xiaocui Chen, and Xiuli Ge for the their help in laboratory determination. This study was financially supported by the National Water Special Project (No. 2012ZX07203-004) and the National Natural Science Foundation of China (No. 31200426).

\section{References}

1. MYHRVOLD N.P., CALDEIRA K. Greenhouse gases, climate change and the transition from coal to low-carbon electricity. Environ. Res. Lett. 7, 014019, 2012.

2. KUROKAWA J., OHARA T., MORIKAWA T., HANAYAMA S., JANSSENS-MAENHOUT G., FUKUI T., KAWASHIMA K., AKIMOTO H. Emissions of air pollutants and greenhouse gases over Asian regions during 20002008: Regional Emission inventory in ASia (REAS) version 2. Atmos. Chem. Phys. 13, 11019, 2013.

3. LAL R. Carbon sequestration. Philos. T. R. Soc. B-Biol.Sci. 363, 815, 2008.

4. LAL R. Soil carbon sequestration impacts on global climate change and food security. Science. 304, 1623, 2004.

5. LAL R. Soil carbon sequestration to mitigate climate change. Geoderma. 123, 1, 2004.

6. WANG S.Q., ZHOU C.H., LI K.R., ZHU S.L., HUANG F.H. China soil organic carbon pool and its spatial distribution characteristics analysis. Ac. Geogr. Sinica. 55, 533, 2000.

7. EULISS JR N.H., GLEASON R.A., OLNESS A., MCDOUGAL R.L., MURKIN H.R., ROBARTS R.D., BOURBONNIERE R.A., WARNER B.G. North American prairie wetlands are important nonforested land-based carbon storage sites. Sci.Total Environ. 361, 179, 2006.

8. MITSCH W.J., NAHLIK A., WOLSKI P., BERNAL B., ZHANG L., RAMBERG L. Tropical wetlands: seasonal hydrologic pulsing, carbon sequestration, and methane emissions. Wetlands Ecol. Manage. 18, 573, 2010.

9. AUSTIN A.T., VIVANCO L. Plant litter decomposition in a semi-arid ecosystem controlled by photodegradation. Nature. 442, 555, 2006.

10. PRESCOTT C.E. Litter decomposition: what controls it and how can we alter it to sequester more carbon in forest soils? Biogeochemistry. 101, 133, 2010.

11. DENEF K., DOTARELI L., BODDEY R.M., SIX J. Microaggregate-associated carbon as a diagnostic fraction for management-induced changes in soil organic carbon in two Oxisols. Soil Biol. Biochem. 39, 1165, 2007.

12. ZHANG W.J., PENG P.Q., TONG C.L., WANG X.L., WU J.S. The composition characteristics and vertical distribution of organic carbon in Dongting Lake wetland. Environ. Sci. 26, 56, 2005.

13. BASILE-DOELSCH I., AMUNDSON R., STONE W.E.E., BORSCHNECK D., BOTTERO J.Y., MOUSTIER S., MASIN S., COLIN F. Mineral control of carbon pools in a volcanic soil horizon. Geoderma. 137, 477, 2007.

14. GONG W., YAN, X.Y., WANG J.Y., HU T.X., GONG Y.B. Long-term manure and fertilizer effects on soil organic matter fractions and microbes under a wheatmaize cropping system in northern China. Geoderma. 149, 318, 2009.

15. RICHARDS A.E., DALAL R.C., SCHMIDT S. Soil carbon turnover and sequestration in native subtropical tree plantations. Soil Biol. Biochem. 39, 2078, 2007.

16. BOONE R.D. Light-fraction soil organic matter: origin and contribution to net nitrogen mineralization. Soil Biol. Biochem. 26, 1459, 1994.

17. TAN Z., LAL R., OWENS L., IZAURRALDE R.C. Distribution of light and heavy fractions of soil organic carbon as related to land use and tillage practice. Soil Till. Res. 92, 53, 2007. 
18. LIU L., XU M., LIN M., ZHANG X. Spatial Variability of Greenhouse Gas Effluxes and Their Controlling Factors in the Poyang Lake in China. Pol. J. Environ. Stud., 22, 749, 2013.

19. HU J., PENG P., JIA G., MAI B., ZHANG G. Distribution and sources of organic carbon, nitrogen and their isotopes in sediments of the subtropical Pearl River estuary and adjacent shelf, Southern China. Mar. Chem. 98, 274, 2006.

20. YANG L., LI G. The research progress of soil inorganic carbon. Chinese J. Soil Sci. 42, 986, 2011.

21. Liu X., Li F.M., Liu D.Q., Sun G.L. Soil organic carbon, carbon fractions and nutrients as affected by land use in semiarid region of Loess Plateau of China. Pedosphere. 20, 46, 2010.

22. WANG J.Y., ZHAO H., HU G.F. Temporal and spatial dynamic change characteristics of non-frost period based on GIS in Shandong Province. Chin. Agric. Sci. Bull. 27, 301, 2011.

23. SZAFRANEK-NAKONIECZNA A., BENNICELLI R.P. Ability of peat soil to oxidize methane and effect of temperature and layer deposition. Pol. J. Environ. Stud. 19, 805, 2010.

24. LIU M.Y., CHANG Q.R., QI Y.B., LIU J., CHEN T. Aggregation and soil organic carbon fractions under different land uses on the tableland of the Loess Plateau of China. Catena. 115, 19, 2014.

25. TAYLOR P.G., TOWNSEND A.R. Stoichiometric control of organic carbon-nitrate relationships from soils to the sea. Nature. 464, 1178, 2010.

26. ZHANG S., LU, X.X., SUN, H., HAN, J., HIGGITT D.L. Geochemical characteristics and fluxes of organic carbon in a human-disturbed mountainous river (the Luodingjiang River) of the Zhujiang (Pearl River), China. Sci. Total Environ. 407, 815, 2009.

27. BRIDGE J.S. Rivers and Floodplains: Forms, Processes, and Sedimentary Record. Wiley-Blackwell Publishing Ltd., Oxford, UK. 2009.

28. ONI S.K., FUTTER M.N., BISHOP K., KOHLER S.J., OTTOSSON-LOFVENIUS M., LAUDON H. Long term patterns in dissolved organic carbon, major elements and trace metals in boreal headwater catchments: trends, mechanisms and heterogeneity. Biogeoscie. Discuss. 9, 19121, 2012.

29. COUTURE S., HOULE D., GAGNON C. Increases of dissolved organic carbon in temperate and boreal lakes in Quebec, Canada. Environ. Sci. Pollut. R. 19, 361, 2012.

30. DENEF K., DOTARELI L., BODDEY R.M. SIX J. Microaggregate-associated carbon as a diagnostic fraction for management-induced changes in soil organic carbon in two Oxisols. Soil Biol. Biochem. 39, 1165, 2007.

31. LANDA M., COTTRELL M.T., KIRCHMAN D.L., BLAIN S., OBERNOSTERER I. Changes in bacterial diversity in response to dissolved organic matter supply in a continuous culture experiment. Aquat. Microb. Ecol. 69, 157, 2013.

32. SCHULYZ P., URBAN N.R. Effects of bacterial dynamics on organic matter decomposition and nutrient release from sediments: A modeling study. Ecol. Model. 210, 1, 2008.

33. KIM J.H., ZELL C., MOREIRA-TURCQ P., PEREZ M.A., ABRIL G., MORTILLARO J.M., JOHAN W.H.W., TARIK M., SINNINGHE DAMATE J.S. Tracing soil organic carbon in the lower Amazon River and its tributaries using GDGT distributions and bulk organic matter properties. Geochim. Cosmochim. Ac. 90, 163, 2012.

34. MARIN-SPIOTTA E.R.I.K.A., SILVER W.L., SWANSTON C.W., OSTERTAG R. Soil organic matter dynamics during 80 years of reforestation of tropical pastures. Global Change Biol. 15, 1584, 2009.

35. PRESCOTT C.E. Litter decomposition: what controls it and how can we alter it to sequester more carbon in forest soils? Biogeochemistry. 101, 133, 2010.

36. ZHANG W.J., PENG P.Q., TONG C.L., WANG X.L., WU J.S. The composition characteristics and vertical distribution of organic carbon in Dongting Lake wetland. Environ. Sci. 26, 56, 2005.

37. POWELL K.M. Quantifying soil organic carbon (SOC) in wetlands impacted by groundwater withdrawals in westcentral Florida. University of South Florida. Tampa, State of Florida, USA. 2008.

38. PRAHL F.G, ERTEL J.R., GONI M.A., SPARROW M.A., EVERSMEYER B. Terrestrial organic carbon contributions to sediments on the Washington margin. Geochim. Cosmochim. Ac. 58, 3035, 1994.

39. CONG W.F., HOFFLAND E., LI L., SIX J., SUN J.H., BAO X.G., ZHANG F.S. Intercropping enhances soil carbon and nitrogen. Global Change Biol. In press. 2014 (DOI: 10.1111/gcb.12738).

40. MILLER A.J., AMUNDSON R., BURKE I.C., YONKER C. The effect of climate and cultivation on soil organic $\mathrm{C}$ and N. Biogeochemistry. 67, 57, 2004.

41. JANSSENS I.A., DIELEMAN W., LUYSSAERT S., SUBKE J.A., REICHSTEIN M., CEULEMANSR., CIAIS P., DOLMAN A.J., GRACE J., MATTEUCCI G., PAPALE D., PIAO S.L., SCHULZE E-D., TANG J., LAW B.E. Reduction of forest soil respiration in response to nitrogen deposition. Nat. Geosci. 3, 315, 2010. 
